\title{
The Relationship between theImplementation of Nutrition Conscious Families (KADARZI) and the Toddler Nutrition Status: A Cross Sectional Study
}

\author{
Sumarlan Juari' ${ }^{1}$, Nirwan Kiming ${ }^{2}$, Anto J. Hadi ${ }^{3}$ \\ ${ }^{1}$ Lecturer in Nutrition, Program Studi Ilmu Gizi, Sekolah Tinggi Ilmu Kesehatan Bhakti Pertiwi Luwu Raya, \\ Palopo, Indonesia, ${ }^{2}$ Lecturers of Nursing, Program Studi Ilmu Keperawatan, Sekolah Tinggi Ilmu Kesehatan \\ Bhakti Pertiwi Luwu Raya, Palopo, Indonesia, ${ }^{3}$ Lecturer of Public Health, Fakultas Kesehatan, Universitas Aufa \\ Royhan, Padangsidimpuan, Sumatera Utara, Indonesia
}

\begin{abstract}
Resolving nutritional problems can be done from the time of pregnancy until the child is 5-year-old. The purpose of this study was to determine the relationship between the application of nutrition awareness family program or Keluarga Sadar Gizi (KADARZI) at the household level with the toddler nutrition status. This study was an observational analytic study, with a cross sectional study research design. The sample consisted of 42 toddlers in Libukang Mandiri Village. Data collection was done by weigh and height measurement and nutrition level behavior questionnaire. The results of the research shows that the KADARZI component has a significant relationship. Itwas the consumption of various foods ( $p$ value $=0.006$ ), weighing regularly (pvalue $=0.017)$. Meanwhile, the nutrition level component has no significant relationship, which was iodized salt consumption ( $p$ value $=0.681$ ), exclusive breast milk ( $p$ value $=0.066$ ), and vitamin A nutrition supplement ( $p$ value $=0.652$ ). Furthermore, there is a significant relationship of KADARZI on a composite basis with toddler nutrition status $(p$ value $=0.044)$. The better the application of KADARZI at the household level, the better the nutrition status of toddlers. It is expected that the mother and all family members should behave well in maintaining nutrition level so that the family members always live healthy and have proper nutritional intake.
\end{abstract}

Keywords: KADARZI; NutritionStatus; Toddler.

\section{Introduction}

The nutritional state is the level of activity in the process of utilizing nutrients for body maintenance, growth, and development as a result of the food and beverages consumption at mealtime ${ }^{(1)}$. Malnutrition can occur from several consequences, namely imbalance intake of nutrients, digestive disease factors, absorption

\section{Corresponding Author:}

\section{Anto J. Hadi}

Department of Public Health, Fakultas Kesehatan, Universitas Aufa Royhan, Padangsidimpuan City, Sumatera Utara, Indonesia

Personal Phone Number: +62 85242877376

e-mail: antoarunraja@gmail.com and infectious diseases ${ }^{(2)}$. Malnutrition in childhood is a global health problem. Data from the World Health Organization (WHO)shows that malnutrition is the cause of under-five mortality, such as in sub-Saharan Africa $28 \%$ and Latin America $7 \%{ }^{(3)}$.

Based on the national basic health research or Riset Kesehatan Dasar (RISKESDAS) in 2018, the prevalence of under-five children with malnutrition decreased from $14.43 \%$ in 2016 to $14.00 \%$ in $2017^{(4)}$. One of the steps in tackling the high rate of malnutrition in Indonesia, the government has implemented the nutrition awareness family programor Keluarga Sadar Gizi (KADARZI). KADARZI is a family with all the members maintaining balanced nutritional behavior and they are able to recognize health and nutrition problems; and able to take steps to overcome nutritional problems encountered by each family member. 
The incidence of malnutrition among toddlers and school-age children in Indonesia shows that nutritional behavior at the family level is still not good, so the problem of malnutrition must continue to get attention because the impact it causes can be long-term problems in households of society ${ }^{(5)}$. In accordance with research conducted by Wijayanti, et al. (2017) on the behavior of a nutritionally conscious family in toddlers in Tulungagung, the result states that children with malnutrition have a negative impact on physical and mental growth, which in turn will hinder learning achievement $^{(6)}$. Another result is a decrease in immune system which causes the loss of a healthy life span for children under five, and a more serious impact is the incidence of disability, high morbidity and accelerated death $^{(7)}$. The purpose of this study was to analyze the relationship between KADARZI behavior at the household level and the nutritional status of children under five.

\section{Method Research}

This type of research is observational study with a cross-sectional method. The dependent variable of this research is toddler nutrition status, while the independent variable is KADARZI behavior. This research was conducted from April to July 2019. The unit of analysis for this study was households with mothers of families as the research respondents. The sampling technique was total sampling and the minimum number of analysis units obtained was 42 samples of toddlers who meet the inclusion criteria, among others they were : 1) toddlers aged 12-59 months who live in the village of Libukang Mandiri Village, Luwu Timur Regency; 2) registeredon the data of healthy family card or Kartu Menuju Sehat (KMS)and/or one way health public serviceor Pos Pelayanan Terpadu (POSYANDU); and 3) not having moderate pain during pre-study or data collection study process. The research questionnaire used is a structured questionnaire or list of questions to collect KADARZI behavior data and anthropometry for assessing the nutritional status of toddlers. The analysis used the chi square test with a confidence level of $95 \%$.

\section{Results}

\section{Table 1. Distribution of KADARZI Behavior and Toddler Nutrition Status in Libukang Mandiri Village, Luwu Timur Regency}

\begin{tabular}{|l|c|c|}
\hline KADARZI Behavior & n & $\begin{array}{c}\text { Percentage } \\
(\%)\end{array}$ \\
\hline Food Intake Variation & 29 & 69 \\
Proper & 13 & 31 \\
Improper & & \\
Weigh Measurement & 35 & 83.3 \\
Regular & 7 & 16.7 \\
Irregular & & \\
Iodized Salt Consumption & 36 & 85.7 \\
Yes & 6 & 14.3 \\
No & & \\
Exclusive Breastfeeding & 28 & 66.7 \\
Yes & 14 & 33.3 \\
No & & \\
Vitamin A Nutrition Supplement & 40 & 95.2 \\
Yes & 2 & 4.8 \\
No & & \\
KADARZI Behavior Implementation & 19 & 45.2 \\
Implement KADARZI & 23 & 54.5 \\
Do Not Implement KADARZI & 0 & \\
Toddler Nutrition Status & 8 & 19.0 \\
Malnutrition & 0 & 0 \\
Less Nutrition & & \\
Good Nutrition & & \\
Over Nutrition & & \\
\hline
\end{tabular}

In Table 1, it can be seen that the KADARZI component achieving the most coverage is the vitamin A nutrition supplement intake as much as $95.2 \%$ while the KADARZI component achieving the lowest coverage is exclusive breastfeeding as much as $66.7 \%$ based on the children who are given exclusive breastfeeding. 
Table 2. The Relationship between KADARZI Behavior with Toddler Nutrition Status in Libukang Mandiri Village, Luwu Timur Regency

\begin{tabular}{|c|c|c|c|c|c|}
\hline \multirow{3}{*}{ KADARZI Behavior } & \multicolumn{4}{|c|}{ Toddler Nutrition Status } & \multirow{3}{*}{ p value } \\
\hline & \multicolumn{2}{|c|}{ Less Nutrition } & \multicolumn{2}{|c|}{ Good Nutrition } & \\
\hline & $\mathbf{n}$ & $\%$ & $\mathbf{n}$ & $\%$ & \\
\hline \multicolumn{6}{|l|}{ Food Intake Variation } \\
\hline Proper & 2 & 4.8 & 27 & 64.3 & 0.006 \\
\hline Improper & 6 & 14.2 & 7 & 16.7 & \\
\hline \multicolumn{6}{|l|}{ Weigh Measurement } \\
\hline Regular & 4 & 9.5 & 31 & 73.8 & 0.017 \\
\hline Irregular & 4 & 9.5 & 3 & 7.2 & \\
\hline \multicolumn{6}{|l|}{ Iodized Salt Consumption } \\
\hline Yes & 7 & 16.7 & 29 & 69.0 & 0.681 \\
\hline No & 1 & 2.4 & 5 & 11.9 & \\
\hline \multicolumn{6}{|l|}{ Exclusive Breastfeeding } \\
\hline Yes & 3 & 7.2 & 25 & 59.5 & 0.066 \\
\hline No & 4 & 11.9 & 9 & 21.4 & \\
\hline \multicolumn{6}{|l|}{ Vitamin A Nutrition Supplement } \\
\hline Yes & 8 & 19.0 & 32 & 76.2 & 0.652 \\
\hline No & 0 & 0 & 2 & 4.8 & \\
\hline \multicolumn{6}{|c|}{ KADARZI Behavior Implementation } \\
\hline Implement KADARZI & 1 & 2.3 & 18 & 42.9 & 0.044 \\
\hline Do Not Implement KADARZI & 7 & 16.7 & 16 & 38.1 & \\
\hline
\end{tabular}

Table 2 is summarized the results of statistical analysis with a confidence level of $95 \%$ and a significance level of $\alpha=0.05$. Table 2 shows the results of this research in $\mathrm{p}$ value. It shows that the KADARZI component has a significant relationship. It was the consumption of various foods $(p$ value $=0.006)$, weighing regularly ( $p$ value $=0.017)$. Meanwhile, the nutrition level component has no significant relationship, which was iodized salt consumption ( $p$ value $=0.681$ ), exclusive breast milk ( $p$ value $=0.066)$, and vitamin A nutrition supplement ( $p$ value $=0.652$ ). Furthermore, there is a significant relationship of KADARZI on a composite basis with toddler nutrition status ( $p$ value $=0.044$ ). It can be said that KADARZI implementation behavior as a whole has a significant relationship with the nutritional status of toddlers.

\section{Discussion}

Fulfillment of toddler nutrition intake depends closely on the behavior patterns of parents. Food consumption patterns can be influenced by the level of awareness of family nutrition. By KADARZI, family is able to recognize, prevent, and overcome nutritional problems for each member ${ }^{(1)}$. One alternative to tackling the high rate of malnutrition in Indonesia is the establishment of KADARZI program held by the government. KADARZI is a family with all the members maintaining balanced nutritional behavior and they are able to recognize health and nutrition problems; and able to take steps to overcome nutritional problems encountered by each family member. The targets of KADARZI program are families with toddlers, families with pregnant women, and mother and/or housewives. One of the indicators of KADARZI is eating a certain and balanced variety of foods. Toddlers are said to eat a variety of foods if the toddler consumes food sources that contain carbohydrates, animal protein, vegetables, and fruit. Toddlers who consume various kinds are still very low because they have not reached the $80 \%$ target set by the Ministry of Health ${ }^{(4)}$. The results of the research conducted in Libukang Mandiri Village showed that the coverage of consumption of a variety of foods in children under five only reached 69.0, it was still lower than the target by the Ministry of Health which is $80 \%$. Based on the results of interviews with mothers of children under five, the consumption of various foods is still low, not reaching $80 \%$ of the target of the Ministry of Health. This is due to various factors such as the absence of an available market in the area and also inadequate access to transportation because the 
respective access is a remote area. In addition, it can also be caused by the factor of mother's knowledge about the benefits of staple food being higher than the benefits of animal and vegetable side dishes as well as vegetables and fruit. It can cause toddlers to not eat a wide variety of foods with proper nutrients ${ }^{(8)}$.

Indicator of weight measurement of KADARZI has reached the target above $80 \%$, namely $83.3 \%$ of children's weigh under five are measured regularly. The result shows that KADARZI has a significant relationship to weigh measurement regularly to the nutritional status of children under five with a $\mathrm{p}$ value $=0.017$. This achievement is due to the support of health facilities and health practitioners in the area by conducting weigh measurement on toddlers regularly. Furthermore, the nutritional status of children as research objects under five can be controlled by health workers. The indicator of iodized salt consumption in Libukang Mandiri Village found that most people in the area have consumed iodized salt with a percentage of $85.7 \%$. However, there are two brands or types of salt used by households that do not contain iodine after the iodine test is carried out. The iodine in salt test has been done by dripping method. If the salt has been dripped, there will be no color change in the salt. However, from the results of the analysis, there was no significant relationship between the use of iodized salt and the toddler nutrition status under five with a value of $p=0.681$. This can be derived from the intake of sufficient protein, carbohydrate, and fat to meet the growth and development needs of children so that the use of iodized salt does not have a significant relationship to the nutritional status of children under five. Although there were $(11.9 \%)$ children who did not consume iodized salt but they had a good nutritional status. The use of iodized salt is also accompanied by proper storage method so that the iodine concentration in salt is maintained. Iodized salt is not resistant to hot temperatures and the use of an open container will cause the salt to evaporate easily which causes the iodine concentration in salt to become smaller ${ }^{(9)}$. Storage of iodized salt should preferably be in a closed container and use iodized salt when cooking when the food is cooked and the food temperature is not too hot.

Indicator of exclusive breastfeeding is limited on breastfeeding only for babies until the age of 6 months. Based on the results of research in the Libukang Mandiri Village, exclusive breastfeeding is still low. There are only $66.7 \%$ of babies getting exclusive breastfeeding from the mothers. This is due to the lack of breastmilk production while most of the people in Libukang Mandiri Village are being farmers, so that most of the mothers work apart from house and from being housewives. They are also garden farmers so that many mothers do not have time to exclusively breastfeed as the area is one of the largest peppers producing areas in South Sulawesi Province. The last KADARZI indicator is vitamin A nutrition supplement in toddlers. Vitamin A plays an important role in the growth of toddlers and vitamin A deficiency can cause xeropthalmia (6). The provision of vitamin A supplements was carried out twice during the past 1 year, namely in February and August. Based on research, toddler who received vitamin A supplements were $95.2 \%$ and this figure has reached the target of $80 \%$. Toddlers who received vitamin A were known based on the results of interviews with mothers and health workers on duty in the Libukang Mandiri Village.

In this study, it is known that there is a significant relationship between KADARZI behavior in the household and the nutritional status of toddlers. Better nutritional status of children under five was found more in families implementing KADARZI than in families who are not implementing KADARZI. This shows that the better the KADARZI family behaves, the better the nutritional status of the toddlers who live in it. KADARZI behavior is very important in realizing good nutritional status for toddlers so that toddler nutrition status is closely related to nutritionally conscious families; the family who are implementing KARDAZI. This is in line with research conducted by Hartono, et al. (2017). The result found the relationship between nutritionconscious family behavior (KADARZI) and clean and healthy living behavior in household arrangements with the nutritional status of toddlers aged 24-59 months ${ }^{(10)}$. Research conducted by Wijayanti, et al. (2017) on the relationship between the application of KARDAZI to the toddler nutrition status under five has a significant relationship ${ }^{(6)}$.

\section{Conclusions and Suggestions}

In this study, it can be concluded that there is a significant relationship between KADARZI behavior at the household level with the toddler nutrition status under five ( $\mathrm{p}$ value $=0.04$ ). It is recommended that health workers increase the socialization of KADARZI contention in family structures. It is also expected that health practitioners and families tag along to increase cross-program and cross-sector cooperation to achieve levels of content at the household level due to KADARZI implementation. 
Ethical Clearance: The results of this study found that eating culture in the local area can affect eating patterns due to geographic conditions, thus impacting on food and energy use so that it affects changes in nutrition status.

Acknowledgement: We would like to thank the people and government of Luwu Timur Regency for their permission and big support to develop this research in the respective area.

Research Funding: Funds used during this research came from private funds.

Conflict of Interest: The author(s) declare that they have no conflict of interest.

\section{References}

1. Ishak S, Hatta H, Hadi AJ. Hubungan Pola Makan, Keterpaparan Media Dan Keturunan Terhadap Kelebihan Berat Badan Pada Siswa Sekolah Dasar. Promot J Kesehat Masy. 2019;9(1):76-84.

2. Setiarini EA, Jazilah J, Waryana W. Tingkat Pengetahuan Gaki Dengan Penanganan Garam Beriodium Oleh Ibu Rumah Tangga Di Desa Belah, Kecamatan Donorojo, Kabupaten Pacitan. Media Gizi Mikro Indones. 2010;1(2):47-54.

3. Organization WH, UNICEF. Trends in maternal mortality: 1990-2015: estimates from WHO, UNICEF, UNFPA, World Bank Group and the United Nations Population Division. 2015;
4. Gizi D, Masyarakat DJK. Buku Saku Pemantauan Status Gizi Tahun 2017. Jakarta Kemenkes RI. 2018;

5. Hadi AJ, Ishak S, Manggabarani S, Said I. Tatalaksana Pola Konsumsi Terhadap Status Gizi Anak Taman Kanak-Kanak. MPPKI (Media Publ Promosi Kesehat Indones Indones J Heal Promot. 2019;2(1):12-20.

6. Wijayanti S, Nindya TS. Hubungan Penerapan Perilaku Kadarzi (Keluarga Sadar Gizi) dengan Status Gizi Balita di Kabupaten Tulungagung. Amerta Nutr. 2017;1(4):379-88.

7. Rahim FK. Faktor risiko underweight balita umur 7-59 bulan. KEMAS J Kesehat Masy. 2014;9(2):115-21.

8. Aditianti A, Prihatini S, Hermina H. Pengetahuan, Sikap dan Perilaku Individu Tentang Makanan Beraneka Ragam sebagai Salah Satu Indikator Keluarga Sadar Gizi (KADARZI). Bul Penelit Kesehat. 2016;44(2):117-26.

9. Sugiani H, Previanti P, Sukrido S, Pratomo U. Penentuan pengaruh pemanasan dan waktu penyimpanan garam beriodium terhadap Kalium Iodat. Chim Nat Acta. 2015;3(2).

10. Hartono $\mathrm{H}$, Widjanarko B. Hubungan perilaku Keluarga Sadar Gizi (KADARZI) dan Perilaku Hidup Bersih Sehat (PHBS) pada tatanan rumah tangga dengan status gizi balita usia 24-59 bulan. J Gizi Indones (The Indones J Nutr. 2016;5(2):88-97. 